\title{
Prevalence of metabolic syndrome among postmenopausal women in South India
}

\author{
Jeyasheela K. ${ }^{1}$, Emily D. Ebenezer ${ }^{1 *}$, Vaibhav Londhe ${ }^{1}$, Thomas V. Paul ${ }^{2}$, \\ Bijesh Yadav ${ }^{3}$, Aruna N. Kekre ${ }^{1}$
}

${ }^{1}$ Department of Obstetrics and Gynecology, ${ }^{2}$ Department of Endocrinology, ${ }^{3}$ Department of Biostatistics, Christian Medical College, Vellore, Tamil Nadu, India

Received: 01 April 2018

Accepted: 30 April 2018

*Correspondence:

Dr. Emily D. Ebenezer,

E-mail: emilydivya@gmail.com

Copyright: (c) the author(s), publisher and licensee Medip Academy. This is an open-access article distributed under the terms of the Creative Commons Attribution Non-Commercial License, which permits unrestricted non-commercial use, distribution, and reproduction in any medium, provided the original work is properly cited.

\begin{abstract}
Background: As the average life expectancy of women extends 20-30 years after menopause, the medical impacts of changes leading to metabolic syndrome on postmenopausal women are significant. The menopausal state has been noted to be an independent risk factor for the occurrence of metabolic syndrome. This study was conducted to look at the prevalence of metabolic syndrome in postmenopausal women.

Methods: A prospective cross sectional study was done and postmenopausal women were assessed for metabolic syndrome using the International Diabetes Federation Criteria.

Results: The prevalence of metabolic syndrome was found to be $64 \%$. Women with metabolic syndrome had a higher systolic blood pressure and larger waist circumference, however did not differ in terms of diabetes and dyslipidemia. There was no significant difference with regards to frequency and severity of menopausal symptoms between women with and without metabolic syndrome.

Conclusions: The increased prevalence of metabolic syndrome in postmenopausal women may be directly due to ovarian insufficiency and indirectly due to metabolic consequences of central fat redistribution with estrogen deficiency.
\end{abstract}

Keywords: Hypertension, Metabolic syndrome, Menopausal symptoms, Postmenopausal, Prevalence, South India

\section{INTRODUCTION}

Menopause is a normal physiological process that often occurs in women at an average age of 50 years. ${ }^{1}$ Mean age at menopause for South Indian women is 48.7 years. ${ }^{2}$ Metabolic syndrome (MetS) comprises a constellation of metabolic abnormalities that includes glucose intolerance (type 2 diabetes and impaired glucose tolerance), insulin resistance, central obesity, dyslipidemia, and hypertension. The menopausal state may be a potential risk factor for the development of metabolic syndrome as its prevalence has been reported to increase after the attainment of menopause..$^{3}$ The menopausal state has been noted to be an independent risk factor for the occurrence of metabolic syndrome, and the risk for metabolic syndrome is said to further increase up to 14 years post menopause. ${ }^{4}$ As the average life expectancy of women extends 20-30 years after menopause, the medical impacts of changes leading to metabolic syndrome on postmenopausal women are significant. ${ }^{5}$

The prevalence of metabolic syndrome increases with increasing aging and increasing glucose intolerance. The increased prevalence of metabolic syndrome in the postmenopausal women may be the directly due to ovarian insufficiency and indirectly due to metabolic consequences of central fat redistribution with estrogen deficiency. Menopausal symptoms have been widely 
reported and studied in developed countries, but less information is available for women of developing countries. Till date, there is no study to determine the prevalence of metabolic syndrome in south Indian population. Hence the objectives of the current research include the assessment of the prevalence of metabolic syndrome among south Indian postmenopausal women attending menopause clinic in Christian Medical College, Vellore.

\section{METHODS}

This is a prospective cross sectional study performed in a tertiary care hospital in southern India. The study protocol was approved by the institutional research and ethics committee. A written informed consent was obtained from all the study participants. 154 postmenopausal women attending Menopause clinic were included. Women with thyroid disease, Cushing's disease, premature menopause, and surgical menopause, use of hormone therapy, chemotherapy, and radiotherapy were excluded.

Postmenopausal women were assessed for MetS based using International Diabetes Federation criteria IDF$2005 .^{6}$ As per this criteria, women with abdominal obesity defined as waist circumference $\geq 80 \mathrm{~cm}$ in South Asians with any two of the four criteria's which included blood pressure $\geq 130 / 85 \mathrm{mmHg}$; fasting blood sugar level $\geq 100 \mathrm{mg} / \mathrm{dl}$; fasting serum triglyceride $\geq 150 \mathrm{mg} / \mathrm{dl}$; highdensity lipoprotein cholesterol $<50 \mathrm{mg} / \mathrm{dl}$ were diagnosed to have MetS. Waist circumference was measured in erect position as the smallest horizontal girth between the costal margins and the iliac crests at minimal respiration using a fibre tape. Blood pressure was recorded in the right arm in sitting position. Venous blood samples were collected after an overnight fasting to measure serum total cholesterol, triglycerides, high-density lipoprotein cholesterol, low-density lipoprotein cholesterol, fasting plasma glucose and serum insulin.

\section{Statistical analysis}

The data was analysed using SPSS (version 16.0; Chicago, IL, USA). All the data were presented as mean and standard deviations. The sample size was calculated on the basis of the expected prevalence of MetS. The reported prevalence of MetS for postmenopausal women was $41 \%$. The clinical variables included patient's age, year of menopause, blood pressure, height and weight. The laboratory characteristics included fasting lipid profile, fasting plasma glucose, and score of menopause rating scale between the MetS and non-MetS groups were compared using Student's t test. The relationship between MetS and lower urinary tract symptoms were evaluated by the Chi-square test and analysis of covariance (ANCOVA). The relationship between the risk factors of MetS and LUTS score was determined by a linear regression test and the Kruskal-Wallis test. A p value of $<0.05$ was considered to be statistically significant.

\section{RESULTS}

This study was conducted in the Department of Obstetrics and Gynaecology outpatient clinic, Christian Medical College Hospital, Vellore from April 2014 to August 2014. The study was approved by the institutional review board and the Ethics Committee of the hospital. One hundred and fifty four menopause women who attended the menopause clinic were recruited for the study.

Table 1: Number of women with metabolic syndrome.

\begin{tabular}{|lll|}
\hline Metabolic syndrome & Number & Percentage \\
\hline Yes & 99 & 64 \\
\hline No & 64 & 36 \\
\hline
\end{tabular}

Number of Women with metabolic syndrome $=99$ $(64 \%)$; Number of women without metabolic syndrome = $55(36 \%)$. The prevalence of metabolic syndrome in our study was found to be $64 \%$.

Table 2: Age wise distribution of study group.

\begin{tabular}{|ll|}
\hline Age (Years) & Number of patients $(\%)$ \\
\hline$<50$ & $29(18.83)$ \\
\hline $50-60$ & $66(42.86)$ \\
\hline$>60$ & $59(38.3 \%)$ \\
\hline
\end{tabular}

Majority of the women were between the fifth and sixth decade.

Table 3: Distribution of metabolic syndrome according to the years since menopause.

\begin{tabular}{|lll|}
\hline $\begin{array}{l}\text { Years since } \\
\text { menopause }\end{array}$ & $\begin{array}{l}\text { Women with } \\
\text { MetS }\end{array}$ & $\begin{array}{l}\text { Women } \\
\text { without MetS }\end{array}$ \\
\hline$<5$ years & 32 & 25 \\
\hline $5-10$ years & 27 & 16 \\
\hline$>10$ yrs & 40 & 14 \\
\hline Total & 99 & 55 \\
\hline
\end{tabular}

MetS: Metabolic Syndrome

Metabolic syndrome was found to be maximum in the women who were more than 10 years postmenopausal.

Table 4: Demographic data.

\begin{tabular}{|llll|}
\hline $\begin{array}{l}\text { Demographic } \\
\text { data }\end{array}$ & $\begin{array}{l}\text { Women } \\
\text { with Mets } \\
(\text { Mean } \pm \text { S.D) }\end{array}$ & $\begin{array}{l}\text { Women } \\
\text { without MetS } \\
(\text { Mean } \pm \text { SD) }\end{array}$ & $\begin{array}{l}\text { P } \\
\text { value }\end{array}$ \\
\hline $\begin{array}{l}\text { Age (years) } \\
\text { Years since }\end{array}$ & $58.22 \pm 7.2$ & $57.60 \pm 5.60$ & 0.659 \\
$\begin{array}{l}\text { menopause } \\
\text { (years) }\end{array}$ & $10.10 \pm 6.7$ & $8.85 \pm 7.29$ & 0.300 \\
\hline $\begin{array}{l}\text { Menopausal } \\
\text { age (years) }\end{array}$ & $48.13 \pm 4.9$ & $48.74 \pm 5.38$ & 0.490 \\
\hline Height $(\mathrm{cms})$ & $152.99 \pm 5.27$ & $152.00 \pm 6.60$ & 0.342 \\
\hline Weight $(\mathrm{kgs})$ & $65.77 \pm 11.52$ & $59.76 \pm 16.64$ & 0.020 \\
\hline BMI $\left(\mathrm{kg} / \mathrm{m}^{2}\right)$ & $28.19 \pm 5.38$ & $25.84 \pm 6.89$ & 0.031 \\
\hline
\end{tabular}


There was no significant difference between two groups with regards to age and number of years since menopause. Patients with metabolic syndrome weigh more than the patients without metabolic syndrome $(\mathrm{P}=0.02)$ and there was a significant difference in their BMI $(\mathrm{P}=0.031)$.

Table 5: Blood pressure measurement and waist circumference.

\begin{tabular}{|llll|}
\hline $\begin{array}{l}\text { Clinical } \\
\text { characteristics }\end{array}$ & $\begin{array}{l}\text { Women with } \\
\text { MetS } \\
\text { Mean } \pm \text { SD }\end{array}$ & $\begin{array}{l}\text { Women } \\
\text { without MetS } \\
\text { Mean } \pm \text { SD }\end{array}$ & $\begin{array}{l}\text { P } \\
\text { Value }\end{array}$ \\
\hline $\begin{array}{l}\text { Systolic blood } \\
\text { pressure } \\
\text { (mmHg) }\end{array}$ & $134.71 \pm 19.53$ & $124.80 \pm 18.345$ & 0.002 \\
$\begin{array}{l}\text { Diastolic blood } \\
\text { pressure } \\
\text { (mmHg) }\end{array}$ & $78.91 \pm 12.15$ & $76.13 \pm 10.62$ & 0.142 \\
$\begin{array}{l}\text { Waist } \\
\text { circumference } \\
(\mathrm{cm})\end{array}$ & $95.63 \pm 9.32$ & $86.35 \pm 13.95$ & 0.000 \\
\hline
\end{tabular}

Patients with metabolic syndrome have significantly high systolic blood pressure $(\mathrm{P}=0.002)$ when compared to women without metabolic syndrome. There was no difference in diastolic blood pressure between two groups. Similarly, the waist circumference of women with metabolic syndrome were measured greater than the women without metabolic syndrome $(\mathrm{P}=0.00)$.

Table 6: Biochemical profile.

\begin{tabular}{|llll|}
\hline $\begin{array}{l}\text { Laboratory } \\
\text { values }\end{array}$ & $\begin{array}{l}\text { Women with } \\
\text { MetS } \\
\text { Mean } \pm \text { S.D }\end{array}$ & $\begin{array}{l}\text { Women } \\
\text { without } \\
\text { MetS } \\
\text { Mean } \pm \text { S.D }\end{array}$ & $\begin{array}{l}\text { P } \\
\text { value }\end{array}$ \\
\hline $\begin{array}{l}\text { Total } \\
\text { cholesterol } \\
\text { (mg/dl) }\end{array}$ & $178.65 \pm 40.38$ & $170.00 \pm 38.82$ & 0.198 \\
\hline $\begin{array}{l}\text { Triglycerides } \\
\text { (mg/dl) }\end{array}$ & $136.45 \pm 70.94$ & $121.75 \pm 96.24$ & 0.324 \\
\hline HDL (mg/dl) & $49.60 \pm 18.605$ & $49.95 \pm 15.57$ & 0.903 \\
\hline LDL (mg/dl) & $114.91 \pm 36.09$ & $111.24 \pm 29.14$ & 0.493 \\
\hline $\begin{array}{l}\text { Fasting glucose } \\
\text { (mg \%) }\end{array}$ & $129.48 \pm 56.35$ & $102.44 \pm 33.93$ & 0.000 \\
\hline
\end{tabular}

Patients with metabolic syndrome had elevated fasting blood glucose when compared to women without metabolic syndrome $(\mathrm{P}=0.00)$. There was no significant difference between both groups interms of lipid profile.

Table 7: Comorbid conditions.

\begin{tabular}{|llll|}
$\begin{array}{l}\text { Comorbid } \\
\text { conditions }\end{array}$ & $\begin{array}{l}\text { Women } \\
\text { with MetS } \\
\text { n=99 }\end{array}$ & $\begin{array}{l}\text { Women } \\
\text { without } \\
\text { MetS n=55 }\end{array}$ & $\begin{array}{l}\% \\
\text { patients }\end{array}$ \\
\hline $\begin{array}{l}\text { fasting } \\
\text { hyperglycemia }\end{array}$ & 81 & 11 & 59.7 \\
\hline $\begin{array}{l}\text { Hypertension } \\
\text { Hyperlipidaemia }\end{array}$ & 68 & 10 & 50.6 \\
\hline
\end{tabular}

The women with metabolic syndrome had higher sugars, hypertension and hyperlipidaemia.

Table 8: Menopausal symptoms versus metabolic syndrome.

\begin{tabular}{|llll|}
\hline $\begin{array}{l}\text { Menopausal } \\
\text { symptoms }\end{array}$ & $\begin{array}{l}\text { Women } \\
\text { with MetS } \\
\text { Mean } \pm \text { SD }\end{array}$ & $\begin{array}{l}\text { Women } \\
\text { without } \\
\text { MetS } \\
\text { Mean } \pm \text { SD }\end{array}$ & $\begin{array}{l}\text { P } \\
\text { Tolue }\end{array}$ \\
\hline $\begin{array}{l}\text { Total somatic } \\
\text { psychological }\end{array}$ & $8.29 \pm 3.76$ & $8.24 \pm 3.85$ & 0.930 \\
\hline $\begin{array}{l}\text { Urogenital } \\
\text { symptoms }\end{array}$ & $3.49 \pm 2.85$ & $2.85 \pm 2.69$ & 0.169 \\
\hline $\begin{array}{l}\text { Total } \\
\text { menopause } \\
\text { rating score }\end{array}$ & $19.53 \pm 7.54$ & $18.38 \pm 8.38$ & 0.403 \\
\hline
\end{tabular}

Patients of both groups had somatic, psychological and urogenital symptoms. There was no significant difference $(\mathrm{P}>0.05)$ between two groups in their total somatic, psychological, urogenital symptoms and the menopause rating scores.

Table 9: Metabolic syndrome and menopausal symptoms.

\begin{tabular}{|lll|}
\hline $\begin{array}{l}\text { Menopausal } \\
\text { symptoms }\end{array}$ & $\begin{array}{l}\text { Women with } \\
\text { MetS } \\
\text { n=99 }\end{array}$ & $\begin{array}{l}\text { Women without } \\
\text { MetS } \\
\text { n=55 }\end{array}$ \\
\hline $\begin{array}{l}\text { Somatic } \\
\text { Hot flushes, } \\
\text { sweating }\end{array}$ & $57(57.5 \%)$ & $29(52.7 \%)$ \\
\hline heart discomfort & $51(51.5 \%)$ & $32(58.1 \%)$ \\
\hline sleeping problem & $73(73.7 \%)$ & $28(50.9 \%)$ \\
\hline $\begin{array}{l}\text { joint and muscular } \\
\text { discomfort }\end{array}$ & $94(94.9 \%)$ & $50(90.9 \%)$ \\
\hline Psychological & $64(64.6 \%)$ & $33(60 \%)$ \\
\hline $\begin{array}{l}\text { Depressive mood } \\
\text { Irritability }\end{array}$ & $56(56.5 \%)$ & $33(60 \%)$ \\
\hline $\begin{array}{l}\text { Anxiety } \\
\text { Physical and } \\
\text { mental exhaustion }\end{array}$ & $85(85.8 \%)$ & $46(83.6 \%)$ \\
\hline $\begin{array}{l}\text { Urogenital } \\
\text { Sexual problems }\end{array}$ & $26(26.2 \%)$ & $17(30.9 \%)$ \\
\hline $\begin{array}{l}\text { Bladder dysfuncton } \\
07(7 \%)\end{array}$ & $06(10.9 \%)$ \\
\hline
\end{tabular}

\section{Somatic symptoms}

Patients with metabolic syndrome had higher joint and muscular discomfort (94.9\%) with sleeping problems in three fourth of women with metabolic syndrome.

The symptoms of hot flushes, sweating and heart discomfort were seen in more than half of women with metabolic syndrome. The women with metabolic syndrome had higher sleep disturbances (73.7\%) when compared to the women without metabolic syndrome $(50.9 \%)$. 


\section{Psychological symptoms}

Patients of both groups had higher prevalence of physical and mental exhaustion (observed in more than $80 \%$ of individuals) although there was no significant difference between two groups. Depressive symptoms were observed in both groups in nearly two-third of study subjects.

\section{Urogenital symptoms}

Sexual problems were observed in nearly one third of study subjects and there was significant difference between two groups. Bladder problems and dryness of vaginal symptoms were observed in less than $10 \%$ of study population.

\section{DISCUSSION}

\section{Age and metabolic syndrome}

As the years since menopause increased, prevalence of MetS increased (Table 3). Mesch et al observed the influence of age versus menopause on metabolic syndrome which has shown that postmenopausal women had a $20-22 \%$ chance of having metabolic syndrome as compared to $0 \%$ in premenopausal women. ${ }^{7}$

\section{Prevalence of metabolic syndrome}

The prevalence of metabolic syndrome (Table 3) using IDF criteria in our study population was 64\% (99/154). Similar criteria has been used by Pandey and colleagues in western India and prevalence of metabolic syndrome was found to be $55 \% .{ }^{8}$ In a study involving 1596 women by Heidari et al documented a prevalence of $44.9 \%$, $57.9 \%$ and $64.3 \%$ in premenopausal, perimenopausal and postmenopausal women respectively which is comparable to our results. ${ }^{9}$ In a study involving 323 women attending gynecology outpatient clinic by Figueiredo et al showed similar prevalence $(64.5 \%)$ using IDF criteria comparable to our findings. ${ }^{10}$

However, contrary findings were documented from other studies too. A cross-sectional study Gorgan province in Iran shows a prevalence of $30 \%$ which was contrary to our findings. ${ }^{11}$ Similarly, published data from Austria, China, Germany, Iran and Canada showed a prevalence of $32.6 \%, 37.34 \%, 36.1 \%, 31 \%$ and $29.6 \%$ respectively which is in contrast to our findings. ${ }^{12,13}$ The prevalence varied in different countries such as in Iran, western India, Argentina and Ecuador had a prevalence rate of $69 \%, 55 \%, 22 \%$ and $41.5 \%$ respectively. ${ }^{7,8,14,15}$

The Study of Women's Health Across the Nation (SWAN) showed that the prevalence of metabolic syndrome prior to the final menstrual period was $32.7 \%$ with $13.7 \%$ of the cohort developing Metabolic syndrome at the time of the final menstrual period. ${ }^{16}$ Chennai Urban Rural Health study(CURES )done in south Indian population found the prevalence of Metabolic syndrome to be $23.2 \%, 18.3 \%$ and $25.8 \%$ using the WHO, ATPIII and IDF definitions, respectively. ${ }^{17}$

Age specific prevalence using NCEP ATPIII criteria $>40$ years ranges between 20 to $30 \%$. Study on postmenopausal women in Austria showed that the prevalence of metabolic syndrome was $32.6 \%{ }^{18}$

These differences in prevalence of metabolic syndrome in different studies could be attributed to selection bias (community/hospital based groups), the type of menopause (natural / surgical), socioeconomic and environmental differences, genetic factors and lifestyle.

\section{Demographic characteristics}

The mean age of menopause observed in our study was 48.2 years which is comparable to study in coastal areas of Karnataka by Bairy et al. ${ }^{2}$ The overall median age at natural menopause was 51.4 in Caucasian and 49.1 in South Asian regions, including India.

Age of menopause in other Asian countries also shows various results: Lahore (49 \pm 3.6$)$ years, Pakistan (47 years), United Arab Emirates (47.3 \pm 3.29$)$, Saudi Arabia (48.94 \pm 0.2$)$, Iran $(49.6 \pm 4.6) .{ }^{19-23}$ As the age of menopause depends on various factors such as inheritance, smoking, number of pregnancies, use of contraceptive pills, there is enough evidence showing wide range of variation in the mean age of menopause across various countries.

A multi-center study performed in seven South-east Asian countries including Hong Kong, Indonesia, Korea, Malaysia, the Philippines, Singapore and Taiwan reported the median age of 51.09 years for menopause. ${ }^{24}$ Such variations among different people could be due to the variations in the reproductive history of individuals, body mass index, and socioeconomic circumstances in childhood such as childhood nutrition, cognition and emotional stress. The importance of the age of onset of the menopause predicts the risk of mortality that is often associated with it. Some reports have documented a 35\% higher risk of mortality with menopause occurring at ages 40-49 years, with risks increasing with a younger age of onset of menopause. ${ }^{25}$

\section{Weight and BMI in metabolic syndrome}

Patients with metabolic syndrome weigh more than the patients without metabolic syndrome (Table 4; $\mathrm{p}$ value $=0.02$ ) and there was a significant difference in the body mass index between two groups ( $p$ value $=0.031$ ). This could be due to the alteration of oestrogen levels with menopause. Estrogen promotes the accumulation of subcutaneous fat rather than visceral fat, and the loss of estrogen with menopause is associated with an increase in visceral fat. ${ }^{26,27}$ 


\section{Waist circumference and metabolic syndrome}

The waist circumference of women with metabolic syndrome were measured greater than the women without metabolic syndrome $(\mathrm{P}=0.00)$ in present study (Table 5). There is a strong correlation between waist circumference and metabolic syndrome. Waist circumference is an important determinant of MetS, but there is a need for population-specific waist circumference cut off point for defining abdominal obesity in women with MetS in this part of the country, as compared to other studies.

Misra et al described that the cardiovascular risk seems to occur at lower waist circumference level in Asian Indians when compared to Caucasians. ${ }^{28}$ This is due to relatively higher truncal and abdominal fat mass as compared to Caucasians and African population despite similar or less average value of waist circumference. High body fat and truncal /abdominal adiposity may increase the insulin resistance and other cardiovascular risk factors to manifest in Asian Indians with lower value of waist circumference than Caucasians. ${ }^{29,30}$ Thus there is a need for further clearer definitions of waist circumference cut offs for MetS in Asians.

\section{Blood pressure and MetS}

Our patients with metabolic syndrome have significantly higher systolic blood pressure $(\mathrm{P}=0.002)$ when compared to women without metabolic syndrome (Table 4). However, there was no difference in diastolic blood pressure between two groups. In a cross sectional study involving 118 post-menopausal women, the authors described the elevation of both systolic and diastolic blood pressure. ${ }^{31}$ Marjani et al. also showed a significantly high diastolic blood pressure among postmenopausal women. ${ }^{11}$

\section{Lipid profile and MetS}

Patients with metabolic syndrome had elevated fasting blood glucose when compared to women without metabolic syndrome $(\mathrm{P}=0.00)$. There was no significant difference between two groups in terms of serum lipid profile (Table 6). In present study dyslipidemia was observed in nearly $83 \%$ of study subjects followed by diabetes $(59.7 \%)$ and hypertension (50.6\%) (Table 7). In a study done on 183 Korean post-menopausal women by Lee and colleagues found positive correlation between high triglyceride levels and somatic symptoms score $(\mathrm{p}=$ 0.044), but other components of MetS did not show a significant correlation $(\mathrm{P}<0.05)$

\section{Relationship between metabolic syndrome and menopausal symptoms}

Menopause predisposes to decreased insulin sensitivity, estrogen deficiency with development of android body habitus along with excessive weight gain. Lack of physical activity contributes to the development of metabolic syndrome in menopause. Age is an independent predisposing risk factor for metabolic syndrome. Postmenopausal obesity leads to greater conversion of androgens to estrogens along with lowered sex hormone binding globulin resulting in endogenous unopposed estrogen.) Patients of both groups showed no significant difference $(\mathrm{P}>0.05)$ in their total somatic, psychological, urogenital symptoms and the menopause rating scores (Table 8). This was contrary to the study by Lee et al in which the metabolic syndrome group had higher frequency of hot flashes and sweating compared to non-metabolic syndrome group $(\mathrm{p}=0.034)$. Increase in the number of metabolic components and increased triglycerides levels were associated with a higher total subscale score of somatic symptom $(\mathrm{p}=0,044, \mathrm{p}=0.039$, respectively). ${ }^{32}$

Fernandez-Alonso et al reported in a 10 year retrospective study done in 574 Caucasian Spanish women, that obesity is associated with more severe menopausal symptoms. ${ }^{33}$ Increase in subcutaneous body fat, inhibits heat dissipation thereby reduces core body temperature, predisposing to increased hot flashes. ${ }^{34}$

Thurston et al. in the Study of Women's Health across the Nation Study (SWAN), showed that an increase in total and subcutaneous obesity was associated with hot flashes. $^{35}$

Chedraui et al assessed the frequency of menopausal symptoms in 325 Ecuadorian postmenopausal women with the menopause-specific quality of life questionnaire (MENQOL). They reported that abdominal obesity was a significant risk factor for hot flashes, depression, and muscle and joint pain; basal hyperglycemia was associated with dry skin and changes in sexual desire; and high tri- glyceride levels were associated with higher rates of sweating and depression. ${ }^{36}$ In a 10-year retrospective study involving 574 Caucasian Spanish women, Fernandez-Alonso et al reported that obesity is associated with more severe menopausal symptoms. ${ }^{24,33}$

Patients with metabolic syndrome had higher joint and muscular discomfort (94.9\%) with sleeping problems in three fourth of women with metabolic syndrome (Table 9). Physical and mental exhaustion were the second most distressing symptoms with least distressing being the urogenital symptoms, which is comparable to previous studies done in India. Anderson et al reported that physical and psychological symptoms were highly significant in Asian women. ${ }^{37}$ It is similar to our study as more than $50 \%$ of women complained of aching in muscles and joints $(67.7 \%)$, feeling tired $(64.7 \%)$, poor memory $(60.5 \%)$, lower backache $(58.8 \%)$, feeling bloated $(55.1 \%)$ and difficulty in sleeping $(51.7 \%)$. The incidence $(<50 \%)$ of hot flushes, fatigue, dry skin, excessive sweating and vaginal dryness is less in our study population when compared to earlier reports $(>50 \%)$. This data is consistent with previous studies conducted by Kaur et al, Chim et al and other studies in 
Asia. ${ }^{38,39}$ Recently, a Malaysian study also found that joint and muscular discomfort was predominantly complained of by $86.6 \%$ women. ${ }^{40}$

\section{CONCLUSION}

The incidence of metabolic syndrome among postmenopausal women is $64 \%$. Women with metabolic syndrome had a higher systolic blood pressure and larger waist circumference, however did not differ in terms of diabetes and dyslipidemia. There was no significant difference with regards to frequency and severity of menopausal symptoms between women with and without metabolic syndrome.

Funding: No funding sources Conflict of interest: None declared

Ethical approval: Not required

\section{REFERENCES}

1. Burger HG, Dudley EC, Robertson DM, Dennerstein L. Hormonal changes in the menopause transition. Recent Prog Horm Res. 2002;57:257-75.

2. Bairy L, Adiga S, Bhat P, Bhat R. Prevalence of menopausal symptoms and quality of life after menopause in women from South India. Aust $\mathrm{N}$ Z J Obstet Gynaecol. 2009 Feb;49(1):106-9.

3. Petri Nahas EA, Padoani NP, Nahas-Neto J, Orsatti FL, Tardivo AP, Dias R. Metabolic syndrome and its associated risk factors in Brazilian postmenopausal women. Climacteric J Int Menopause Soc. 2009 Oct;12(5):431-8.

4. López-López R, Huerta R, Malacara JM. Age at menopause in women with type 2 diabetes mellitus. Menopause N Y N. 1999;6(2):174-8.

5. Al-Azzawi F. The menopause and its treatment in perspective. Postgrad Med J. 2001 May;77(907):292304.

6. Alberti KGMM, Zimmet P, Shaw J. Metabolic syndrome--a new world-wide definition. A Consensus Statement from the International Diabetes Federation. Diabet Med J Br Diabet Assoc. 2006 May;23(5):469-80.

7. Mesch VR, Boero LE, Siseles NO, Royer M, Prada M, Sayegh F, et al. Metabolic syndrome throughout the menopausal transition: influence of age and menopausal status. Climacteric J Int Menopause Soc. 2006 Feb;9(1):40-8.

8. Pandey S, Srinivas M, Agashe S, Joshi J, Galvankar $\mathrm{P}$, Prakasam CP, et al. Menopause and metabolic syndrome: A study of 498 urban women from western India. J -Life Health. 2010;1(2):63-9.

9. Heidari R, Sadeghi M, Talaei M, Rabiei K, Mohammadifard N, Sarrafzadegan N. Metabolic syndrome in menopausal transition: Isfahan Healthy Heart Program, a population based study. Diabetol Metab Syndr. 2010;2:59.

10. Figueiredo Neto JA de, Figuerêdo ED, Barbosa JB, Barbosa F de F, Costa GRC, Nina VJ da S, et al.
Metabolic syndrome and menopause: cross-sectional study in gynecology clinic. Arq Bras Cardiol. 2010 Sep;95(3):339-45.

11. Marjani A, Moghasemi S. The Metabolic Syndrome among Postmenopausal Women in Gorgan. Int $\mathbf{J}$ Endocrinol [Internet]. 2012 [cited 2014 Aug 9];2012. Available http://www.ncbi.nlm.nih.gov/pmc/articles/PMC3296 $160 /$

12. Delavar MA, Lye M-S, Khor GL, Hanachi P, Hassan STBS. Prevalence of metabolic syndrome among middle aged women in Babol, Iran. Southeast Asian J Trop Med Public Health. 2009 May;40(3):612-28.

13. Deibert P, König D, Vitolins MZ, Landmann U, Frey I, Zahradnik H-P, et al. Effect of a weight loss intervention on anthropometric measures and metabolic risk factors in pre- versus postmenopausal women. Nutr J. 2007 Oct 25;6:31.

14. Ainy E, Mirmiran P, Zahedi Asl S, Azizi F. Prevalence of metabolic syndrome during menopausal transition Tehranian women: Tehran Lipid and Glucose Study (TLGS). Maturitas. 2007 Oct 20;58(2):150-5.

15. Hidalgo LA, Chedraui PA, Morocho N, Alvarado M, Chavez D, Huc A. The metabolic syndrome among postmenopausal women in Ecuador. Gynecol Endocrinol Off J Int Soc Gynecol Endocrinol. 2006 Aug;22(8):447-54.

16. Janssen I, Powell LH, Crawford S, Lasley B, SuttonTyrrell K. Menopause and the metabolic syndrome. Arch Intern Med. 2008 Jul 28;168(14):1568-75.

17. 17. Deepa M, Farooq S, Datta M, Deepa R, Mohan V. Prevalence of metabolic syndrome using WHO, ATPIII and IDF definitions in Asian Indians: the Chennai Urban Rural Epidemiology Study (CURES34). Diabetes Metab Res Rev. 2007 Feb 1;23(2):12734.

18. Ponholzer A, Temml C, Rauchenwald M, Marszalek $\mathrm{M}$, Madersbacher S. Is the metabolic syndrome a risk factor for female sexual dysfunction in sexually active women? Int J Impot Res. 2007;20(1):100-4.

19. Wasti S, Robinson SC, Akhtar Y, Khan S, Badaruddin N. Characteristics of menopause in three socioeconomic urban groups in Karachi, Pakistan. Maturitas. 1993 Jan;16(1):61-9.

20. Rizk DE, Bener A, Ezimokhai M, Hassan MY, Micallef R. The age and symptomatology of natural menopause among United Arab Emirates women. Maturitas. 1998 Jun;29(3):197-202.

21. Yahya S, Rehan N. Age, pattern and symptoms of menopause among rural women of Lahore. J Ayub Med Coll Abbottabad. 2002 Sep;14(3):9-12.

22. Addar M, El Desouki M, Babay Z. Correlates of age at menopause and osteoporosis in Saudi women. Clin Exp Obstet Gynecol. 2005;32(2):135-7.

23. Mohammad K, Sadat Hashemi SM, Farahani FKA. Age at natural menopause in Iran. Maturitas. 2004 Dec 10;49(4):321-6. 
24. Boulet MJ, Oddens BJ, Lehert P, Vemer HM, Visser A. Climacteric and menopause in seven South-east Asian countries. Maturitas. 1994 Oct;19(3):157-76.

25. Dorman JS, Steenkiste AR, Foley TP, Strotmeyer ES, Burke JP, Kuller LH, et al. Menopause in type 1 diabetic women: is it premature? Diabetes. 2001 Aug;50(8):1857-62.

26. Krotkiewski M, Björntorp P, Sjöström L, Smith U. Impact of obesity on metabolism in men and women. Importance of regional adipose tissue distribution. J Clin Invest. 1983 Sep;72(3):1150-62.

27. Lee SW, Jo HH, Kim MR, Kwon DJ, You YO, Kim JH. Association between menopausal symptoms and metabolic syndrome in postmenopausal women. Arch Gynecol Obstet. 2012 Feb;285(2):541-8.

28. Misra A, Vikram NK, Gupta R, Pandey RM, Wasir JS, Gupta VP. Waist circumference cutoff points and action levels for Asian Indians for identification of abdominal obesity. Int J Obes 2005. 2006 Jan;30(1):106-11.

29. Chandalia M, Abate N, Garg A, Stray-Gundersen J, Grundy SM. Relationship between generalized and upper body obesity to insulin resistance in Asian Indian men. J Clin Endocrinol Metab. 1999 Jul;84(7):2329-35.

30. Vikram NK, Pandey RM, Misra A, Sharma R, Devi JR, Khanna N. Non-obese (body mass index $<25$ $\mathrm{kg} / \mathrm{m}^{2}$ ) Asian Indians with normal waist circumference have high cardiovascular risk. Nutr Burbank Los Angel Cty Calif. 2003 Jun;19(6):503-9.

31. Jouyandeh Z, Nayebzadeh F, Qorbani M, Asadi M. Metabolic syndrome and menopause. J Diabetes Metab Disord. 2013;12(1):1.

32. Lee SW, Jo HH, Kim MR, You YO, Kim JH. Association between obesity, metabolic risks and serum osteocalcin level in postmenopausal women. Gynecol Endocrinol. 2012 Jun 1;28(6):472-7.

33. Fernández-Alonso AM, Cuadros JL, Chedraui $P$, Mendoza M, Cuadros AM, Pérez-López FR. Obesity is related to increased menopausal symptoms among Spanish women. Menopause Int. 2010 Sep;16(3):105-10.

34. Freedman RR. Pathophysiology and treatment of menopausal hot flashes. Semin Reprod Med. 2005 May;23(2):117-25.

35. Thurston RC, Sowers MR, Sutton-Tyrrell K, Everson-Rose SA, Lewis TT, Edmundowicz D, et al. Abdominal adiposity and hot flashes among midlife women. Menopause N Y N. 2008 Jun;15(3):429-34.

36. Chedraui P, Hidalgo L, Chavez D, Morocho N, Alvarado M, Huc A. Menopausal symptoms and associated risk factors among postmenopausal women screened for the metabolic syndrome. Arch Gynecol Obstet. 2007 Mar;275(3):161-8.

37. Anderson D, Yoshizawa T, Gollschewski S, Atogami F, Courtney M. Menopause in Australia and Japan: effects of country of residence on menopausal status and menopausal symptoms. Climacteric J Int Menopause Soc. 2004 Jun;7(2):165-74.

38. Punyahotra S, Dennerstein L, Lehert P. Menopausal experiences of Thai women. Part 1: Symptoms and their correlates. Maturitas. 1997 Jan;26(1):1-7.

39. Fu S-Y, Anderson D, Courtney M. Cross-cultural menopausal experience: comparison of Australian and Taiwanese women. Nurs Health Sci. 2003 Mar;5(1):77-84.

40. Age of Menopause and Menopausal Symptoms Among Malaysian Women Who Referred to Health Clinic in Malaysia., Vol. 7, No. 3, SEMJ [Internet]. [cited 2014 Sep 3]. Available at http://semj.sums.ac.ir/vol7/jul2006/menopause.htm.

Cite this article as: Jeyasheela K, Ebenezer ED, Londhe V, Paul TV, Yadav B, Kekre AN. Prevalence of metabolic syndrome among postmenopausal women in South India. Int J Reprod Contracept Obstet Gynecol 2018;7:2364-70. 